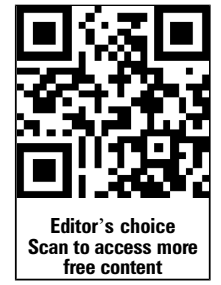

${ }^{1}$ Departments of Family Medicine and Orthopaedics and Sports Medicine, University of Washington, Seattle, Washington, USA ${ }^{2}$ Department of Family Medicine, University of Washington, Seattle, Washington, USA

${ }^{3}$ Department of Sports Medicine, Aspetar Orthopaedic and Sports Medicine Hosptial, Doha, Qatar

${ }^{4}$ Cardiovascular Sciences Research Center, St George's University of London, London, UK

\section{Correspondence to} Dr Kimberly G Harmon, Departments of Family Medicine and Orthopaedics and Sports Medicine, University of Washington, 3800 Montlake Boulevard, Seattle, WA 98195 , USA; kharmon@uw.edu

This paper is also being published in the August issue of the BMJ's cardiology journal, Heart

(1) Co-published

Accepted 2 June 2014

\title{
Incidence of sudden cardiac death in athletes: a state-of-the-art review
}

\author{
Kimberly G Harmon, ${ }^{1}$ Jonathan A Drezner, ${ }^{2}$ Mathew G Wilson, ${ }^{3}$ Sanjay Sharma ${ }^{4}$
}

\section{ABSTRACT}

Sudden cardiac death (SCD) is the leading medical cause of death in athletes; however, the precise incidence is unknown. The objectives of this review were to examine studies on the rate of SCD in athletes, assess the methodological strengths and weaknesses used to arrive at estimates, compare studies in athletes with estimates in similar populations and arrive at an approximation of the incidence of SCD based on the best available evidence. A comprehensive literature search was performed in PubMed using key terms related to SCD in athletes. Articles were reviewed for relevance and included if they contained information on the incidence of $S C D$ in athletes or young persons up to the age of 40. The reference list from each manuscript was reviewed for additional relevant articles. The methods for case identification were examined, as well as the inclusion and exclusion criteria and the precision of the population denominator studied. Thirteen studies were found investigating the rate of SCD in athletes who ranged in age from 9 to 40. An additional 15 incidence studies were located examining the rate of SCD in other populations under the age of 40 . Rates of SCD varied from 1:917 000 to 1:3000. Studies with higher methodological quality consistently yielded incidence rates in the range of 1:40 000 to 1:80 000 . Some athlete subgroups, specifically men, African-American/ black athletes and basketball players, appear to be at higher risk. The incidence of SCD in athletes is likely higher than traditional estimates which may impact the development of more effective prevention strategies.

\section{INTRODUCTION}

There is widespread agreement that sudden cardiac death (SCD) is the leading medical cause of death in athletes. Current estimates of the incidence of SCD in athletes range from almost one in a million $^{1}$ to $1: 23000^{2}$ athletes per year, while some subpopulations of athletes are reported at even higher risk with an incidence of 1 in $3000 .^{3}$ The most commonly acknowledged incidence of SCD in athletes is 1 in 200000 , although recent studies and a closer examination of methodologies have challenged this estimate as too low. ${ }^{3-5}$ Contrasts in current estimates are largely due to differing methodology and heterogeneous population comparisons. In order to accurately estimate incidence, a precise numerator (cases identified) and denominator (population) are required. Several factors affect case identification including the definition of an athlete, methods of data acquisition, lack of mandatory reporting requirements in most settings, the inclusion or exclusion of cases based on time and location of the event, inclusion of all cardiac events (including survivors) versus only those resulting in death and the population examined. Selection and calculation of the denominator also varies widely in precision. An accurate understanding of the incidence of cardiovascular events in athletes is absolutely critical to the development and evaluation of screening guidelines. This review will critically examine and compare incidence studies in order to better understand the incidence of SCD in athletes.

\section{METHODS}

A comprehensive literature search was performed in PubMed using the terms: incidence, sudden cardiac death, sudden death, sudden cardiac arrest, etiology, pathology, registry, athlete, young, children and adolescents. Articles were reviewed for relevance and included if they contained information on the incidence of SCD in athletes or young persons up to the age of 40 . The reference list from each manuscript was reviewed for additional relevant articles. SCD was defined as a sudden unexpected death due to cardiac causes, or sudden death in a structurally normal heart that had no other explanation and a history consistent with cardiac-related death, that occurred within $1 \mathrm{~h}$ of symptom onset in a person without known cardiac disease or an unwitnessed death occurring within $24 \mathrm{~h}$ of the person having been alive and symptom free.

\section{UNDERSTANDING THE METHODOLOGY}

The key to accurately interpreting any study on incidence is to understand the methods used to identify cases, the criteria for case inclusion or exclusion, and what population is being studied. Incidence and aetiology vary considerably with age, making conclusions within broad age ranges difficult to draw. Investigations of well-defined populations such as high school or college athletes may have more important application. Some reports include only exertional deaths, only those which occur within an hour of exercise, or only while playing for a school-sponsored team and reported to insurance companies. This will substantially underestimate the overall incidence of SCD. ${ }^{346-9}$

\section{Exertional SCD or SCD occurring at any time?}

The primary objective of prevention programmes is early detection of disease, in order to prevent adverse health and catastrophic events from ever occurring. While cardiovascular screening in athletes is generally thought justified due to an increased risk of cardiovascular events during exertion, programmes designed to prevent SCD are not intended to prevent SCD only during sport or only during a school-sponsored activity, but rather to promote athlete health and prevent SCD at any 
time. Many of the pathologies associated with SCD in young athletes may present with lethal arrhythmias at rest or during sleep; therefore, it is the incidence of SCD inclusive of SCD occurring outside of sport, not just the incidence of SCD occurring during exertion, which is necessary to accurately identify athlete risk.

\section{Case identification: mandatory reporting, media reports, registries and insurance claims}

Mandatory reporting systems afford the most reliable results, although few of these exist. Registries depend on passive collection methods and are subject to ascertainment and selection bias. Many studies rely on the use of media reports to identify cases; however, this results in underestimating SCD incidence. In one retrospective cohort study from Denmark, only $20 \%$ of athlete deaths identified by death certificates were found through an extensive media search. ${ }^{6}$ In another retrospective cohort study of a high profile US college athlete population, media reports identified only $56 \%$ of total cases. ${ }^{3}$ Media reports are likely to be less reliable prior to widespread use of the Internet and in lower profile athletes (younger athletes, female athletes and non-revenue sports). Studies using catastrophic insurance claims as the only source of case identification also are likely to underestimate the incidence of SCD. Insurance claims provide information only on deaths which occur during schoolsponsored sporting events, and do not include cases that occur during individual activity, unofficial practices or deaths which occur outside of sport. In fact, catastrophic insurance claims missed $80 \%$ of SCD cases in a study using an internal reporting structure for the NCAA. Consequently, incidence assessments based on media reports and catastrophic insurance claims should be considered a minimum estimate.

\section{The importance of the denominator}

Incidence calculations are based on a ratio, thus if the population being examined (the denominator) is not well defined the final estimate can be highly variable. The most accurate incidence estimates will be in a distinct group with well-defined demographics. Estimating the overall number of athletes based on population statistics, in large age ranges or multiple demographic areas without an overarching authority is fraught with potential error. Additionally, some studies may examine sudden deaths in a population as opposed to all deaths in a population. ${ }^{78}$ When comparing the relative risk of death, eliminating subtypes such as accidental deaths from the overall analysis significantly changes the ratios and can skew results making entities appear more or less common. Consequently, an accurate denominator is critical to precise incidence estimates.

\section{Impact of age on SCD incidence}

The rate of SCD varies considerably with age. ${ }^{10-13}$ In young athletes ( $<30$ years old), the aetiology of SCD usually involves a genetic structural or primary electrical cardiac disorder. In older athletes, the rate of atherosclerotic heart disease increases rapidly, particularly after the age of 25-30. Thus, studies inclusive of large age ranges or a substantial proportion of older participants can vary significantly and may disproportionately affect incidence rates. $^{14} 15$

\section{Should SCA be included in incidence calculations?}

Finally, some incidence calculations examine only SCD, while others also include sudden cardiac arrest (SCA) victims that survive. SCA is an important endpoint with potential morbidity, but it is more difficult to track using the most commonly employed methods. SCA is often not reported in the media and in most settings there is no requirement to report SCA. In early reports of SCD before public access defibrillation programmes, SCA events likely resulted in death, so the need to recognise SCA survivors and SCD victims in incidence calculations was less apparent. With the implementation of emergency action plans and the widespread use of automated external defibrillators (AEDs), survival rates from SCA in athletes now rival that of other public access defibrillation programmes, with one recent prospective observational study demonstrating an $89 \%$ survival rate. ${ }^{9}$ Survival from SCA may drastically decrease the overall incidence numbers of SCD. Primary prevention programmes are intended to identify athletes at risk and prevent SCA from ever occurring, so to properly evaluate screening programmes the inclusion of SCA and SCD in the assessment of incidence is warranted.

In fact, the identification of potentially lethal cardiac abnormalities during preparticipation screening appears to be universally supported. The American College of Cardiology (ACC), the American Heart Association (AHA), the European Society of Cardiology and the IOC all endorse that the identification of potentially serious medical conditions including cardiovascular disease that place athletes at risk for safe sports participation is the primary reason for screening. ${ }^{16-19}$ The latest edition of the Pre-Participation Physical Evaluation Monograph endorsed by six US medical societies and the AHA also states the primary objective of the preparticipation examination is to 'screen for conditions that may be life threatening or disabling'. ${ }^{20}$ With such widespread agreement that the objective of screening is the identification of potentially life-threatening conditions, the effectiveness of preparticipation screening should be understood not just in terms of SCD but also in terms of SCA with survival.

\section{EVALUATING THE STUDIES}

\section{Estimates of SCD in general populations of athletes}

There are 13 studies reporting on SCD in athletes with 5 reporting on SCD incidence in general populations of athletes, most with broad age ranges from 8 to $40^{6821-23}$ (table 1). The first study to report on the rate of SCD in athletes was a 1995 study which employed a retrospective cohort design and utilised the National Center for Catastrophic Sports Injury Research database from 1983 to 1993 to evaluate sudden deaths in high school and college athletes. An overall SCD rate of 1:300 000 was estimated with a rate of 1:1300000 in women. ${ }^{21}$ While this effort highlighted an area without much previous research, this study relied on passive collection methods and media reports in the preinternet era for case identification, and undoubtedly cases were missed. In addition, the denominator was imprecise. However, 1:300 000 became the starting point for the incidence of SCD in athletes.

The largest report of SCD in a general population of athletes comes from the US Registry for Sudden Death in Athletes (USRSDA). ${ }^{8} \quad 24$ The USRSDA has collected information on sudden death in athletes since 1980. The primary sources of information are media searches, electronic databases and selfreports, that is, next-of-kin. The number of cases identified has increased steadily by approximately $6 \%$ annually as media search strategies have improved. ${ }^{8}$ SCA and SCD were included which contrasted the previous study. The denominator of the athlete population was set at 10.7 million although there is no descriptor of how this was arrived at; in fact, in two previous reports using the same database incidence rates were not reported due to 'unavoidable selection bias' and the certainty of significantly underestimating the rate. ${ }^{25} 26$ In this study, the 
Table 1 Incidence studies in general populations of atheltes

\begin{tabular}{|c|c|c|c|c|c|c|c|c|c|c|c|c|c|c|}
\hline Author & Year & Country & Study design & Case identification & Denominator & $\begin{array}{l}\text { Exertional } \\
\text { deaths of } \\
\text { all? }\end{array}$ & $\begin{array}{l}\text { SCD or } \\
\text { SCA }+ \text { SCD }\end{array}$ & $\begin{array}{l}\text { Years } \\
\text { studied }\end{array}$ & Population & Incidence & $\begin{array}{l}\text { Number } \\
\text { of years }\end{array}$ & $\begin{array}{l}\text { Age } \\
\text { range }\end{array}$ & $\begin{array}{l}\text { Mean } \\
\text { age }\end{array}$ & $\begin{array}{l}\text { Number of } \\
\text { cardiac } \\
\text { deaths }\end{array}$ \\
\hline $\begin{array}{l}\text { Van } \\
\text { Camp }^{21}\end{array}$ & 1996 & USA & $\begin{array}{l}\text { Retrospective } \\
\text { cohort }\end{array}$ & $\begin{array}{l}\text { National Center for } \\
\text { Catastrophic Injury } \\
\text { Research and media } \\
\text { database }\end{array}$ & $\begin{array}{l}17 \text { most popular sports, participants in } \\
\text { NCAA, NFHS, NAIA, NAJC, added } \\
\text { together, conversion factor to account } \\
\text { multisport athletes used 'based on } \\
\text { discussions with representatives from the } \\
\text { national organisations'. } 1.9 \text { for high school } \\
\text { and } 1.2 \text { for college }\end{array}$ & Exertional & $S C D$ & 1983-1993 & $\begin{array}{l}\text { College } \\
\text { athletes and } \\
\text { high school }\end{array}$ & $1: 300000$ & 10 & $17-24$ & 17 & 100 \\
\hline Maron $^{26}$ & 1996 & USA & $\begin{array}{l}\text { Retrospective } \\
\text { cohort }\end{array}$ & $\begin{array}{l}\text { US Registry for Sudden } \\
\text { Death in Athletes }\end{array}$ & $\begin{array}{l}\text { 'Unavoidable selection bias and certainly } \\
\text { significantly underestimate' }\end{array}$ & All & $S C D$ & 1985-1995 & Athletes & - & 10 & $12-40$ & 17 & 134 \\
\hline Maron $^{25}$ & 2003 & USA & $\begin{array}{l}\text { Retrospective } \\
\text { cohort }\end{array}$ & $\begin{array}{l}\text { US Registry for Sudden } \\
\text { Death in Athletes }\end{array}$ & Not possible b/c of selection bias & All & $S C D$ & $1985-2000$ & Athletes & - & 25 & $9-40$ & 17 & 286 \\
\hline Corrado $^{22}$ & 2003 & Italy & $\begin{array}{l}\text { Prospective } \\
\text { cohort study }\end{array}$ & $\begin{array}{l}\text { Mandatory death } \\
\text { reporting }\end{array}$ & Registered Italian athletes & All & $S C D$ & 1979-1999 & $\begin{array}{l}\text { Athletes and } \\
\text { young people }\end{array}$ & $\begin{array}{l}\text { 1:47 } 600 \\
\text { athlete } \\
1: 142900 \\
\text { young people }\end{array}$ & 20 & $12-35$ & 23 & 55 \\
\hline Maron $^{8}$ & 2009 & USA & $\begin{array}{l}\text { Retrospective } \\
\text { cohort }\end{array}$ & $\begin{array}{l}\text { US Registry for Sudden } \\
\text { Death in Athletes }\end{array}$ & $\begin{array}{l}\text { Estimated } 10.7 \text { million athletes }<39 \\
\text { participating in sports during 2000-2006 } \\
\text { (method not described) }\end{array}$ & All & $\mathrm{SCA}+\mathrm{SCD}$ & 1980-2006 & Athletes & 1:163934 & 27 & $8-39$ & 18 & 690 \\
\hline Holst $^{6}$ & 2010 & Denmark & $\begin{array}{l}\text { Retrospective } \\
\text { cohort }\end{array}$ & $\begin{array}{l}\text { Review of death } \\
\text { certificates-then } \\
\text { autopsies if available } \\
-15 \text { sports related } \\
\text { SCD (SrSCD) }\end{array}$ & Denmark population statistics & $\begin{array}{l}\text { All and } \\
\text { sports related }\end{array}$ & $S C D$ & $2000-2006$ & $\begin{array}{l}\text { Athletes and } \\
\text { young people }\end{array}$ & $\begin{array}{l}1: 82645 \mathrm{SrSCD} \\
1: 26595 \\
\text { general pop }\end{array}$ & 7 & $12-35$ & 26 & $\begin{array}{l}15 \mathrm{SrSCD} \\
470 \mathrm{SCD}\end{array}$ \\
\hline Steinvil ${ }^{23}$ & 2011 & Israel & $\begin{array}{l}\text { Retrospective } \\
\text { cohort }\end{array}$ & $\begin{array}{l}\text { Retrospective review of } \\
\text { two Israeli newspapers } \\
\text { by two media } \\
\text { researchers }\end{array}$ & $\begin{array}{l}45000 \text { registered competitive athletes in } \\
2009 \text {, extrapolated the growth of the } \\
\text { Israeli population age } 10-40 \text { since } 1985 \\
\text { based on that figure and allowed for a } \\
\text { presumed doubling of the sporting } \\
\text { population }\end{array}$ & All & SCD & $\begin{array}{l}1985- \\
19971998 \\
-2009\end{array}$ & Athletes & $\begin{array}{l}\text { 1st- } \\
1: 393702 \text { nd- } \\
1: 37593\end{array}$ & 24 & $12-44$ & 24 & 24 \\
\hline
\end{tabular}

SCA, sudden cardiac arrest; SCD, sudden cardiac death. 
incidence of SCD for US athletes aged 8-39 from 2001 to 2006 was calculated at 1:164 $000{ }^{8}$ The strengths of this retrospective cohort study are the long time frame of the registry and the number of cases identified. The limitations of the incidence calculation include a broad age range, underestimation of events and an approximated denominator.

Estimates of SCD in athletes in other parts of the world are impacted by the use of different methods for case ascertainment. In the Veneto region of Italy, there is a mandatory reporting system for juvenile sudden death with autopsies performed by specialist cardiovascular pathologists. In a prospective cohort study from 1979 to 1999 , the reported rate of SCD was 1:47 000 in athletes aged $12-35 .{ }^{22}$ This study presented a more accurate case identification and a precise denominator and the rate was higher than in previous studies. In a subsequent report from the same Italian dataset, the initial rate of SCD from 1979 to 1981 was 1:28 000, and after implementation of a national screening programme, the rate of SCD decreased by $89 \%$ to 1:250 000 in 2006 suggesting benefit to a cardiac screening programme inclusive of ECG. ${ }^{27}$

The disparity in incidence numbers between Italy and the USA have been attributed to the differing ethnic populations with differing risks for SCD and has led some to suggest that the USA need not consider more intensive screening strategies. ${ }^{28}$ It is more likely that the differing SCD incidence is due to the disparate methods of measuring incidence: retrospective cohorts based on media reports, catastrophic insurance claims and registries subject to ascertainment bias with uncertain denominators, versus a prospective mandatory reporting system with a reliable denominator.

Other studies of SCD incidence using a broad age range of competitive athletes were performed in Israel and Denmark. ${ }^{6} 23$ The Israeli study was a retrospective cohort study which relied on the retrospective search of two major newspapers for case identification in athletes aged 12-44. The denominator was developed by ascertaining the number of registered athletes in 2009 and then extrapolating retrospectively, based on population statistics and the predicted growth in the percentage of the population engaged in athletic activity over time, the number of competitive athletes from 1985 onwards. The incidence of SCD was estimated to be 1:39 000 from 1985 to 1997 and 1:38 000 from 1998 to $2009 .{ }^{23}$ Critical weaknesses of this study include case identification using only a retrospective search of two newspapers, inclusion of a 24-year interval with variable media attention to athlete SCD, the broad age range with rates of SCD largely influenced by inclusion of older athletes and the imprecise denominator. The authors concluded that an ECG screening programme started in 1998 showed no benefit in the prevention of SCD in athletes, basing this claim on a flawed scientific foundation. ${ }^{4}$ The retrospective cohort study from Denmark reviewed death certificate and autopsy information for case identification and used population statistics as a denominator. ${ }^{6}$ The investigators reported a rate of SCD of 1:83 000 in athletes aged 12-35. The primary weakness in this study was the ability to accurately identify competitive athletes from the available information.

\section{SCD in US college athletes}

As the incidence of SCD varies considerably with age, the ability to examine populations with more narrowly defined age ranges is important. All studies on SCD incidence in competitive athletes outside the USA include broad age ranges. In the USA, three retrospective cohort studies specifically investigate the incidence of SCD in college athletes aged 17-24, with rates ranging from 1:43000 to $1: 67000^{3729}$ (table 2). In the first, a survey

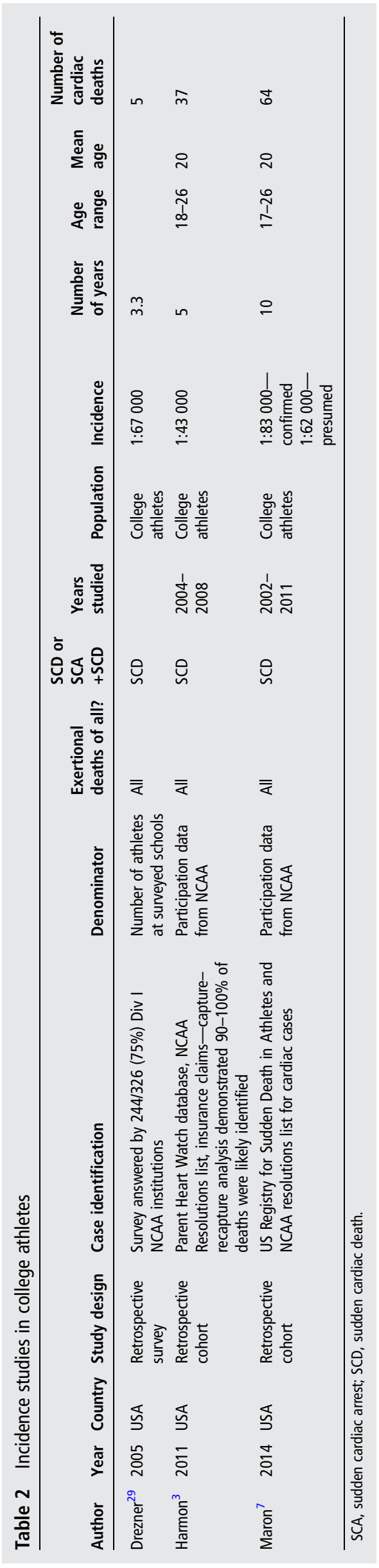


Table 3 Incidence studies in high school students

\begin{tabular}{|c|c|c|c|c|c|c|c|c|c|c|c|c|c|c|}
\hline Author & $\begin{array}{l}\text { Year } \\
\text { published }\end{array}$ & Country & Study design & Case identification & Denominator & $\begin{array}{l}\text { Exertional } \\
\text { deaths of all? }\end{array}$ & $\begin{array}{l}\text { SCD or } \\
\text { SCA } \\
+\mathrm{SCD}\end{array}$ & $\begin{array}{l}\text { Years } \\
\text { studied }\end{array}$ & Population & Incidence & $\begin{array}{l}\text { Number of } \\
\text { years }\end{array}$ & $\begin{array}{l}\text { Age } \\
\text { range }\end{array}$ & $\begin{array}{l}\text { Mean } \\
\text { age }\end{array}$ & $\begin{array}{l}\text { Number of } \\
\text { cardiac } \\
\text { deaths }\end{array}$ \\
\hline Maron ${ }^{31}$ & 1998 & USA & $\begin{array}{l}\text { Retrospective } \\
\text { cohort }\end{array}$ & Insurance claims & $\begin{array}{l}\text { Minnesota State High } \\
\text { School League }\end{array}$ & $\begin{array}{l}\text { Exertional during } \\
\text { school sponsored } \\
\text { sport }\end{array}$ & $S C D$ & $\begin{array}{l}1985- \\
1997\end{array}$ & $\begin{array}{l}\text { High school } \\
\text { athlete }\end{array}$ & $\begin{array}{l}1: 217000 \text { overall } \\
1: 129000 \text { male } 0 \\
\text { for female }\end{array}$ & 12 & $16-17$ & 16.5 & 3 \\
\hline Drezner $^{2}$ & 2009 & USA & $\begin{array}{l}\text { Cross-sectional } \\
\text { survey }\end{array}$ & $\begin{array}{l}1710 \text { high schools with } \\
\text { AEDs surveyed for SCA or } \\
\text { SCD }\end{array}$ & $\begin{array}{l}\text { Number of student } \\
\text { athletes reported by } \\
\text { schools }\end{array}$ & $\begin{array}{l}\text { SCA or SCD } \\
\text { occurring on } \\
\text { campus }\end{array}$ & $\begin{array}{l}\text { SCA } \\
+ \text { SCD }\end{array}$ & $\begin{array}{l}2006- \\
2007\end{array}$ & $\begin{array}{l}\text { High school } \\
\text { athletes }\end{array}$ & $\begin{array}{l}1: 23000 \text { SCA } \\
+ \text { SCD 1:46000 } \\
\text { SCD }\end{array}$ & $\begin{array}{l}\text { Within } \\
6 \text { months of } \\
\text { survey }\end{array}$ & $14-17$ & 16 & 14 \\
\hline Maron 32 & 2013 & USA & $\begin{array}{l}\text { Retrospective } \\
\text { cohort }\end{array}$ & $\begin{array}{l}\text { US Registry of Sudden } \\
\text { Death in Athletes }\end{array}$ & $\begin{array}{l}\text { Minnesota State High } \\
\text { School League }\end{array}$ & Exertional & $S C D$ & $\begin{array}{l}1986- \\
2011\end{array}$ & $\begin{array}{l}\text { High school } \\
\text { athletes }\end{array}$ & $1: 150000$ & 26 & $12-18$ & 16 & 13 \\
\hline Roberts $^{1}$ & 2013 & USA & $\begin{array}{l}\text { Retrospective } \\
\text { cohort }\end{array}$ & Insurance claims data & $\begin{array}{l}\text { Minnesota State High } \\
\text { School League }\end{array}$ & $\begin{array}{l}\text { Exertional during } \\
\text { school sponsored } \\
\text { sport }\end{array}$ & $S C D$ & $\begin{array}{l}1993- \\
2012\end{array}$ & $\begin{array}{l}\text { High school } \\
\text { athletes }\end{array}$ & $\begin{array}{l}\text { 1:416 } 666 \text { over } \\
\text { last decade } \\
\text { 1:917 } 000\end{array}$ & 19 & $12-19$ & - & 4 \\
\hline Toresdahl $^{34}$ & 2014 & USA & $\begin{array}{l}\text { Prospective } \\
\text { observational }\end{array}$ & $\begin{array}{l}2149 \text { schools followed for } \\
\text { SCA+SCD which occurred } \\
\text { on school campus }\end{array}$ & $\begin{array}{l}\text { Number of student } \\
\text { athletes reported by } \\
\text { schools }\end{array}$ & $\begin{array}{l}\text { SCA or SCD } \\
\text { occurring on } \\
\text { campus }\end{array}$ & $\begin{array}{l}\text { SCA } \\
+ \text { SCD }\end{array}$ & $\begin{array}{l}2009- \\
2011\end{array}$ & $\begin{array}{l}\text { High school } \\
\text { athletes }\end{array}$ & $\begin{array}{l}1: 87719 \text { SCA } \\
+ \text { SCD 1:57 000 } \\
\text { male SCA+SCD }\end{array}$ & 2 & $14-18$ & _- & $\begin{array}{l}18 S C A+S C D \\
2 S C D\end{array}$ \\
\hline Drezner $^{5}$ & 2014 & USA & $\begin{array}{l}\text { Retrospective } \\
\text { cohort }\end{array}$ & Media reports & NFHS & All & $\begin{array}{c}S C A \\
+S C D\end{array}$ & $\begin{array}{l}2003- \\
2013\end{array}$ & $\begin{array}{l}\text { High school } \\
\text { athletes }\end{array}$ & $\begin{array}{l}\text { 1:153 } 846 \text { SCD } \\
1: 71 \text { 428 SCA } \\
1: 21277 \text { male } \\
\text { basketball }\end{array}$ & 10 & $14-18$ & - & $\begin{array}{l}6 \mathrm{SCD} \\
7 \mathrm{SCD}\end{array}$ \\
\hline Harmon $^{35}$ & 2014 & USA & $\begin{array}{l}\text { Retrospective } \\
\text { cohort }\end{array}$ & Media reports & NFHS & All & $\begin{array}{l}\text { SCA } \\
+S C D\end{array}$ & $\begin{array}{l}2007- \\
2013\end{array}$ & $\begin{array}{l}\text { High school } \\
\text { athletes }\end{array}$ & $\begin{array}{l}\text { 1:63 } 988 \text { SCA } \\
\text { 1:41 } 662 \text { male } \\
\text { 1:33 } 815 \text { male } \\
\text { basketball }\end{array}$ & 5 & $14-18$ & _- & $\begin{array}{l}74 \text { SCD } \\
35 \text { SCA }\end{array}$ \\
\hline
\end{tabular}

SCA, sudden cardiac arrest; SCD, sudden cardiac death. 
was sent to NCAA institutions regarding SCD and AED use over an average of 3.3 years and an SCD rate of 1:67 000 was calculated based on 244 responding institutions. ${ }^{29}$ In the second, a database of NCAA college athlete deaths was compiled from the Parent Heart Watch media database, the NCAA Resolutions database and NCAA insurance claims. This database looked retrospectively at 5 years of deaths from 2004 to 2008, identifying approximately nine cases of SCD per year, ${ }^{3}$ with the cardiovascular cause of these deaths confirmed by autopsy review in a subsequent study. ${ }^{30}$ NCAA participation statistics for race, sex and sport were used for the denominator. In this study an overall SCD rate of 1:43000 was calculated; additionally, high-risk subgroups were identified such as men with a risk of 1:33 000, African-Americans with a risk of 1:18 000, basketball athletes with a risk of 1:11 000 and Division I male basketball players with an alarming risk of $1: 3000 .^{3}$ A similar study reviewed sudden deaths in NCAA athletes over a 10 -year period from 2002 to $2011 .^{7}$ In this study the USRSDA and NCAA Resolutions database was used for case identification, reporting approximately six cases of SCD per year with an incidence of 1:62 $000 .^{7}$ Thus, these three different studies using variable methodology all arrive at reasonably comparable figures for an incidence of SCD in college athletes of approximately 1:50 000, with some subgroups at higher risk.

\section{SCD in US high school athletes}

High school athletes aged 14-18 provide another well-defined age subgroup to determine incidence. Seven US studies examined high schools athletes with wide variation in the reported rate of SCD from 1:23 000 to 1:917 $000^{12}$ (table 3). An initial incidence estimate of 1:217000 in high school athletes came from Minnesota in a retrospective cohort study with case identification reliant on catastrophic insurance claim data. ${ }^{31} \mathrm{~A}$ recent follow-up study also limited to catastrophic insurance claims reported an incidence of 1:917000 over the past decade. ${ }^{1}$ Catastrophic insurance claims only capture deaths which occur during school-sponsored events or practices and significantly underestimate the total incidence of SCD. Highlighting this point was a retrospective review of the very same population of Minnesota high school athletes but using media reports for case identification. Media reports identified 13 cases in Minnesota high school athletes (all in boys), including 6 cases of SCD and 7 additional cases of SCA in student athletes who survived. Catastrophic insurance claims detected only one of six deaths $(17 \%)$ that occurred in athletes during the same study period and only one of four deaths which occurred while playing sports. ${ }^{5}$ The three exertional deaths missed by catastrophic insurance claims occurred in athletes when participating in club sports or unofficial practices. In a recent retrospective cohort study of Minnesota state high school athletes using the USRSDA, 13 cardiovascular related sudden deaths were identified over a 26-year period with an estimated incidence of 1:150 $000 .^{32}$ On closer examination and comparison of studies, catastrophic insurance claims identified only four deaths over 19 years and during an overlapping time period the USRSDA identified 13 deaths over 26 years, again emphasising the limitations of using catastrophic insurance claims as the sole means for case identification. Furthermore, insurance claims data limited only to deaths and not SCA will vastly underestimate the rate of major cardiovascular events in athletes.

Other studies have found higher rates of SCD in high school athletes. In a cross-sectional survey of 1710 high schools, an SCD rate of 1:46000 was found, with a rate of 1:23 000 when SCA was included. ${ }^{2}$ While this study is limited by the potential for reporting bias, these numbers may underestimate risk as only events which occurred on high school campus were captured; events which occurred away from campus or while sleeping were not included. In two retrospective population-based cohort studies, up to one-third of SCD occurred while sleeping, illustrating the limits of only including school-based events. ${ }^{6} 33$ A recent 2-year prospective cross-sectional study of 2149 high schools demonstrated an overall SCA rate of 1:88 $000 .^{34}$ While the prospective monitoring provided more rigorous surveillance, this study also examined events only occurring on school campus. Lastly, a preliminary study examined SCA and SCD in high school athletes in six US states, representing $36 \%$ of the US high school population and almost 20 million athlete seasons over 5 years from 2007 to $2013 .{ }^{35}$ Media reports were used for case identification and the denominator was defined using data from the National Federation of State High School Associations (NFHS), with an SCA/SCD incidence rate of 1:63000 calculated. $^{35}$ The incidence in male high school athletes was $1: 41000$ and in male basketball athletes was $1: 33000 .^{35}$

In conclusion, studies of incidence in high school athletes are more difficult to interpret with a wide range of variables and methods accounting for different incidence rates. The methodological limitations of incidence studies in high school athletes must be recognised. Current assessments of incidence either focus on a fraction of the day (school hours), ${ }^{1} 2 \quad 313234$ only account for SCD occurring with certain activities, ${ }^{1} 3132$ include only SCD and not SCA with survival ${ }^{13132} 34$ or rely on media reports for case identification. ${ }^{5}{ }^{36}$ All these issues result in incomplete case identification and an underestimation of the incidence of SCD. Based on available studies, we believe that 1:50 000 to $1: 80000$ should be considered a minimum estimate range for the incidence of SCD in high school athletes with male athletes at higher risk.

\section{Comparisons to similar non-athlete populations}

Fifteen studies report on the incidence of SCD in young, nonathlete populations, primarily generated by retrospective cohort studies using death certificates, coroner's databases and autopsies for case identification. SCD estimates range from 1:22 000 to $1: 128000$, depending on the age of the population examined. ${ }^{6} 10 \quad 14 \quad 33 \quad 36-40$ There are several prospective populationbased studies using emergency medical services databases which include SCA and SCD and provide more rigorous methodology to consider ${ }^{13}{ }^{41-43}$ (table 4). The most comprehensive of these prospective studies spanned 30 years and reported an SCA/SCD rate of 1:69 000 in 14-24 year olds and 1:22 000 in 25-35-year olds in King County, Washington. ${ }^{43}$

Four studies have compared the relative risk of SCD or SCA in competitive athletes with the general population. It is generally accepted that intense physical exertion increases the likelihood of SCA in those with underlying cardiovascular disorders. An Italian prospective cohort study reported a 2.5 times relative risk for SCD in competitive athletes compared with agematched non-athletes. ${ }^{22}$ In a prospective cohort study in France, a 4.5 times relative risk of sports-related SCD was reported in competitive athletes compared with recreational sports participants. ${ }^{32}$ Similarly, a prospective observational study in US high schools with over 4.1 million total student-years and over 1.5 million student athlete-years of surveillance found a 3.6 times relative risk for SCA on campus in high school student athletes versus student non-athletes. ${ }^{13}{ }^{34}$ In contrast, in a retrospective review of death certificates and media reports in Denmark, investigators reported a rate of SCD in athletes aged 12-35 that was 3.3 times lower than the general population. ${ }^{6}$ 
Table 4 Incidence studies in the military and general population

\begin{tabular}{|c|c|c|c|c|c|c|c|c|c|c|c|c|c|c|}
\hline Author & Year & Country & Study design & Case identification & Denominator & $\begin{array}{l}\text { Exertional } \\
\text { deaths of all? }\end{array}$ & $\begin{array}{l}\text { SCD or } \\
\text { SCA } \\
+ \text { SCD }\end{array}$ & $\begin{array}{l}\text { Years } \\
\text { studied }\end{array}$ & Population & Incidence & $\begin{array}{l}\text { No. of } \\
\text { years }\end{array}$ & $\begin{array}{l}\text { Age } \\
\text { range }\end{array}$ & $\begin{array}{l}\text { Mean } \\
\text { age }\end{array}$ & $\begin{array}{l}\text { No. of } \\
\text { cardiac } \\
\text { deaths }\end{array}$ \\
\hline Eckart $^{44}$ & 2004 & USA & $\begin{array}{l}\text { Retrospective } \\
\text { cohort }\end{array}$ & $\begin{array}{l}\text { Mandatory reporting of all } \\
\text { deaths to DOD recruit mortality } \\
\text { registry with autopsy data }\end{array}$ & Numbers from DOD & All & SCD & $\begin{array}{l}1977- \\
2001\end{array}$ & $\begin{array}{l}\text { Military } \\
\text { recruits }\end{array}$ & $1: 10000$ & 25 & $18-35$ & 19 & 108 \\
\hline Gunnarson $^{36}$ & 2006 & Iceland & $\begin{array}{l}\text { Retrospective } \\
\text { cohort }\end{array}$ & $\begin{array}{l}\text { Death certificates and autopsy } \\
\text { reports reviewed }\end{array}$ & $\begin{array}{l}\text { Iceland population } \\
\text { statistics }\end{array}$ & All & SCD & $\begin{array}{l}1974- \\
2004\end{array}$ & $\begin{array}{l}\text { Young } \\
\text { people }\end{array}$ & $1: 68000$ & 30 & $12-35$ & & 45 \\
\hline Atkins $^{41}$ & 2009 & $\begin{array}{l}\text { USA and } \\
\text { Canada }\end{array}$ & $\begin{array}{l}\text { Prospective } \\
\text { cohort study }\end{array}$ & $\begin{array}{l}\text { EMS responding to confirmed } \\
\text { cardiac cases }\end{array}$ & Population statistics & All & $\begin{array}{l}\text { SCA } \\
+ \text { SCD }\end{array}$ & $\begin{array}{l}2005- \\
2007\end{array}$ & $\begin{array}{l}\text { Young } \\
\text { people }\end{array}$ & $1: 49000$ & 3 & $12-19$ & 16.4 & 193 \\
\hline Chugh $^{42}$ & 2009 & USA & $\begin{array}{l}\text { Prospective } \\
\text { population based }\end{array}$ & $\begin{array}{l}\text { EMS responding to confirmed } \\
\text { cardiac cases }\end{array}$ & Population statistics & All & $\begin{array}{l}\text { SCA } \\
+ \text { SCD }\end{array}$ & $\begin{array}{l}2002- \\
2005\end{array}$ & $\begin{array}{l}\text { Young } \\
\text { people }\end{array}$ & 1:58 828 & 3 & $10-14$ & - & 2 \\
\hline Papdakis $^{37}$ & 2009 & UK & $\begin{array}{l}\text { Retrospective } \\
\text { cohort }\end{array}$ & Review of death certificates & Population statistics & All & & $\begin{array}{l}2002- \\
2005\end{array}$ & $\begin{array}{l}\text { Young } \\
\text { people }\end{array}$ & $1: 55000$ & 4 & $1-34$ & - & 3409 \\
\hline Holst $^{6}$ & 2010 & Denmark & Retrospect cohort & $\begin{array}{l}\text { Death certificates and autopsy } \\
\text { reports reviewed if available } \\
(67 \%)\end{array}$ & Population statistics & All & SCD & $\begin{array}{l}2000- \\
2006\end{array}$ & $\begin{array}{l}\text { Young } \\
\text { people }\end{array}$ & $1: 35000$ & 7 & $1-35$ & 26.4 & 15 \\
\hline Solberg ${ }^{14}$ & 2010 & Norway & $\begin{array}{l}\text { Retrospective } \\
\text { cohort }\end{array}$ & $\begin{array}{l}\text { Norwegian cause of death } \\
\text { registry—validated with autopsy } \\
\text { and medical records }\end{array}$ & Population statistics & Exertional & SCD & $\begin{array}{l}1979- \\
1998\end{array}$ & $\begin{array}{l}\text { Young } \\
\text { people }\end{array}$ & 1:111 111 & 20 & $15-34$ & 27 & 23 \\
\hline Cooper $^{40}$ & 2011 & USA & $\begin{array}{l}\text { Retrospective } \\
\text { cohort }\end{array}$ & $\begin{array}{l}\text { Automated data from } 4 \text { health } \\
\text { plans - study carried out to } \\
\text { compare ADHD users to } \\
\text { non-users }\end{array}$ & $\begin{array}{l}\text { Number of those } \\
2-24 \text { in health } \\
\text { plan }\end{array}$ & All & $\begin{array}{l}\text { SCA } \\
+ \text { SCD }\end{array}$ & $\begin{array}{l}1986- \\
2005\end{array}$ & $\begin{array}{l}\text { Young } \\
\text { people }\end{array}$ & $1: 32258$ & 19 & $2-24$ & 11.1 & 81 \\
\hline Eckart $^{12}$ & 2011 & USA & $\begin{array}{l}\text { Retrospective } \\
\text { cohort }\end{array}$ & $\begin{array}{l}\text { Mandatory reporting of all } \\
\text { deaths to DOD mortality registry } \\
\text { with autopsy data }\end{array}$ & DOD statistics & All & $S C D$ & $\begin{array}{l}1998- \\
2008\end{array}$ & Military & $\begin{array}{l}<20-1: 2 \text { 967 320-24 } \\
1: 4098325-29- \\
1: 3012030-35-1: 25000\end{array}$ & 10 & $18-34$ & - & 298 \\
\hline Margey $^{39}$ & 2011 & Ireland & $\begin{array}{l}\text { Retrospective } \\
\text { cohort }\end{array}$ & $\begin{array}{l}\text { Death certificate review with } \\
\text { autopsy confirmation }\end{array}$ & Population statistics & All & SCD & $\begin{array}{l}2005- \\
2007\end{array}$ & $\begin{array}{l}\text { Young } \\
\text { people }\end{array}$ & $\begin{array}{l}1: 350001: 20000 \text { males } \\
1: 77000 \text { female }\end{array}$ & 3 & $15-35$ & 25 & 116 \\
\hline Marjion $^{13}$ & 2011 & France & Prospective & $\begin{array}{l}\text { EMS responding to confirmed } \\
\text { cardiac cases }\end{array}$ & Population statistics & Sports related & $\begin{array}{l}\text { SCA } \\
+ \text { SCD }\end{array}$ & $\begin{array}{l}2005- \\
2010\end{array}$ & $\begin{array}{l}\text { Young } \\
\text { people }\end{array}$ & $\begin{array}{l}\text { 1:102 } 000 \text { competitive } \\
\text { athletes (10-35) }\end{array}$ & 5 & $12-75$ & 46 & 820 \\
\hline Meyer $^{43}$ & 2012 & USA & $\begin{array}{l}\text { Prospective } \\
\text { population based }\end{array}$ & $\begin{array}{l}\text { EMS responding to confirmed } \\
\text { cardiac cases }\end{array}$ & Population statistics & All & $\begin{array}{l}\text { SCA } \\
+ \text { SCD }\end{array}$ & $\begin{array}{l}1980- \\
2009\end{array}$ & $\begin{array}{l}\text { Young } \\
\text { people }\end{array}$ & $\begin{array}{l}14-241: 69.00025-35 \\
1: 22700\end{array}$ & 30 & $\begin{array}{l}14-24 \\
25-35\end{array}$ & - & $\begin{array}{l}\text { 14-24: } 60 \\
\text { 25-35: } 245\end{array}$ \\
\hline Pilmer $^{10}$ & 2013 & $\begin{array}{l}\text { Ontario, } \\
\text { Canada }\end{array}$ & $\begin{array}{l}\text { Retrospective } \\
\text { cohort }\end{array}$ & From coroner's database & Population statistics & All & SCD & 2008 & $\begin{array}{l}\text { Young } \\
\text { people }\end{array}$ & 1:34 $000(19-29)$ & 1 & $2-40$ & - & 174 \\
\hline Pilmer $^{38}$ & 2014 & $\begin{array}{l}\text { Ontario, } \\
\text { Canada }\end{array}$ & $\begin{array}{l}\text { Retrospective } \\
\text { cohort }\end{array}$ & From coroner's database & Population statistics & All & SCD & $\begin{array}{l}2005- \\
2009\end{array}$ & $\begin{array}{l}\text { Young } \\
\text { people }\end{array}$ & 1:128 000 & 5 & $1-19$ & 12 & 116 \\
\hline Winkle $^{33}$ & 2014 & Denmark & $\begin{array}{l}\text { Retrospective } \\
\text { cohort }\end{array}$ & $\begin{array}{l}\text { Death certificates, autopsy } \\
\text { reports and health records } \\
\text { reviewed }\end{array}$ & Population statistics & All & SCD & $\begin{array}{l}2000- \\
2006\end{array}$ & $\begin{array}{l}\text { Young } \\
\text { people }\end{array}$ & 1:90909 & 7 & $1-18$ & 13 & 62 \\
\hline
\end{tabular}

SCA, sudden cardiac arrest; SCD, sudden cardiac death. 
The US military is perhaps the best source to calculate incidence rates of SCD in active individuals, due to the mandatory reporting of deaths with standard autopsy protocols and access to premortem medical records and clearly defined denominators. Although individuals in the military do not meet standard definitions of a competitive athlete, military personnel undergo regular, intense physical training, especially for recruits during basic training. Given the rich source of quality data and the similar median age to college athletes (19 years), these studies in military recruits are a good comparator. In a retrospective cohort study of 6.3 million recruit years over 25 years, the rate of SCD in military recruits was $1: 10000 .{ }^{44}$ In a follow-up study examining the rate of SCD in active duty military personnel who undergo regular physical activity but not necessarily the intense activity experienced during basic training by recruits, the rate of SCD was approximately 1:30000 in persons under the age of 30 , with the expected increase in overall incidence and death secondary to atherosclerotic heart disease in older military personnel. ${ }^{12}$ These military studies in exercising young adults with better methodology also support a higher SCD incidence in athletes than initial estimates.

\section{LOOKING AHEAD}

Better quality studies with mandatory reporting of SCD and SCA are required to acquire more accurate information in athletes. Ideally, when SCD does occur there would be a standardised autopsy from a cardiac pathologist accompanied by a molecular autopsy. A pilot study of such a system in five US states with required reporting of sudden death in youth followed by death investigation is currently being funded by the National Heart Lung and Blood Institute, with data collection to begin in 2015. Likewise, in January 2014 the NCAA passed legislation requiring all NCAA institutions to report cases of catastrophic injury (including SCA) or death beginning August 2014. Both these initiatives will provide a rich source of prospective data in a defined population to give more accurate information regarding the incidence and aetiology of SCA/SCD in athletes.

\section{CONCLUSIONS}

It is widely acknowledged that SCD is the leading medical cause of death in athletes although its exact incidence remains unclear. Use of media reports or catastrophic insurance claims as the primary method for case identification underestimates the risk of SCD in athletes. The best available evidence together with a close examination of reporting methods for case identification and population definitions, suggests that the incidence of SCD in athletes is higher than initial estimates. An overall incidence of 1:50 000 in young athletes is a reasonable estimate based on a synthesis of existing information, primarily retrospective cohort studies and prospective observational or cross-sectional studies, and when compared with similar populations such as the military where the quality of available data is greater. Male athletes are consistently found to be at greater risk, and there appears to be a disproportionately higher risk among male basketball athletes which requires further investigation. Variability in incidence rates is largely due to differences in methodology including the reliability of case identification, the accuracy of population denominators and the cases which are excluded or included. The goal of cardiovascular screening programmes is to identify potentially lethal cardiovascular disorders, and all SCA and SCD should be included in incidence calculations if a valid assessment of prevention strategies is to be considered. Accurate incidence numbers are important in understanding if screening programmes limited to athletes are warranted, cost effective and effectual. It must be acknowledged that unrecognised limitations and misinterpretations of current data have perpetuated an underestimation of the incidence of SCD and perhaps impeded progress towards the evaluation of more effective screening programmes.

\section{Summary points}

- Sudden cardiac death $(S C D)$ is the leading medical cause of death in athletes.

- There are widely varying estimates of SCD due to differences in methodology including the reliability of case identification, age range of athletes studied, the accuracy of population denominators and the cases which are excluded or included.

- There is widespread agreement that athletes should undergo cardiovascular screening prior to participation in sport, and the primary objective of this screening is the identification of potentially life-threatening disorders.

- To fully understand the cardiovascular risks in athletes and the potential to prevent major cardiovascular events through screening, incidence estimates should include sudden cardiac arrest (SCA) survivors and SCD cases occurring at any time (sleep, rest, exertion).

- Based on a synthesis of best available information, an SCD incidence rate of 1:50 000 in college athletes and 1:50 0001:80 000 in high school athletes should be considered a minimum.

- Some subpopulations such as males, black/AfricanAmericans and basketball athletes appear to be at higher risk.

\section{Research questions}

- What is the incidence of SCA and SCD in high school and college athletes based on prospective studies with mandatory reporting requirements and defined populations?

- What is the aetiology of SCD in different athlete populations utilising expert cardiac forensic pathologists and molecular autopsy?

- Why are basketball athletes at higher risk of SCA and SCD compared with other athletes?

- Are athletes at greater risk of SCA and SCD than non-athletes using prospective methodology and mandatory reporting mechanisms?

Contributors All authors contributed substantially to the manuscript. KGH was responsible for the planning and primary draft of the manuscript. JAD, SS and MGW were responsible for planning as well as revisions, corrections, rewriting and editing of drafts.

Competing interests None.

Provenance and peer review Not commissioned; internally peer reviewed.

\section{REFERENCES}

1 Roberts WO, Stovitz SD. Incidence of sudden cardiac death in Minnesota high school athletes 1993-2012 screened with a standardized pre-participation evaluation. J Am Coll Cardiol 2013;62:1298-301. 
2 Drezner JA, Rao AL, Heistand J, et al. Effectiveness of emergency response planning for sudden cardiac arrest in United States high schools with automated external defibrillators. Circulation 2009:120:518-25.

3 Harmon KG, Asif IM, Klossner D, et al. Incidence of sudden cardiac death in national collegiate athletic association athletes. Circulation 2011:123:1594-600.

4 Drezner JA, Harmon KG, Borjesson M. Incidence of sudden cardiac death in athletes: where did the science go? Br J Sports Med 2011;45:947-8.

5 Drezner JA, Harmon KG, Marek JC. Incidence of sudden cardiac arrest in Minnesota high school student athletes: the limitations of catastrophic insurance claims. J Am Coll Cardiol 2014:63:1455-6.

6 Holst AG, Winkel BG, Theilade J, et al. Incidence and etiology of sports-related sudden cardiac death in Denmark -implications for preparticipation screening. Heart Rhythm 2010;7:1365-71.

7 Maron BJ, Haas TS, Murphy CJ, et al. Incidence and causes of sudden death in U.S. College athletes. J Am Coll Cardiol 2014;63:1636-43.

8 Maron BJ, Doerer JJ, Haas TS, et al. Sudden deaths in young competitive athletes. Analysis of 1866 deaths in the United States, 1980-2006. Circulation 2009;119:1085-92.

9 Drezner JA, Toresdahl BG, Rao AL, et al. Outcomes from sudden cardiac arrest in US high schools: a 2-year prospective study from the National Registry for AED Use in Sports. Br J Sports Med 2013;47:1179-83.

10 Pilmer CM, Porter B, Kirsh JA, et al. Scope and nature of sudden cardiac death before age 40 in Ontario: a report from the cardiac death advisory committee of the office of the chief coroner. Heart Rhythm 2013;10:517-23.

11 Winkel BG, Holst AG, Theilade J, et al. Nationwide study of sudden cardiac death in persons aged 1-35 years. Eur Heart J 2011;32:983-90.

12 Eckart RE, Shry EA, Burke AP, et al. Sudden death in young adults: an autopsy-based series of a population undergoing active surveillance. J Am Coll Cardiol 2011:58:1254-61.

13 Marijon E, Tafflet M, Celermajer DS, et al. Sports-related sudden death in the general population. Circulation 2011;124:672-81.

14 Solberg EE, Gjertsen F, Haugstad E, et al. Sudden death in sports among young adults in Norway. Eur J Cardiovasc Prev Rehabil 2010;17:337-41.

15 Eckart RE. Sudden death in the young-did sensationalism trump science? Heart Rhythm 2013;10:524-5.

16 Maron BJ, Douglas PS, Graham TP, et al. Task force 1: preparticipation screening and diagnosis of cardiovascular disease in athletes. J Am Coll Cardiol 2005;45:1322-6.

17 Corrado D, Pelliccia A, Bjornstad HH, et al. Cardiovascular pre-participation screening of young competitive athletes for prevention of sudden death: proposal for a common European protocol. Consensus statement of the study group of sport cardiology of the working group of cardiac rehabilitation and exercise physiology and the working group of myocardial and pericardial diseases of the European society of cardiology. Eur Heart J 2005;26:516-24.

18 Ljungqvist $A$, Jenoure $P$, Engebretsen $L$, et al. The International Olympic Committee (IOC) Consensus Statement on periodic health evaluation of elite athletes March 2009. Br J Sports Med 2009:43:631-43.

19 Maron BJ, Thompson PD, Ackerman MJ, et al. Recommendations and considerations related to preparticipation screening for cardiovascular abnormalities in competitive athletes: 2007 update: a scientific statement from the American Heart Association Council on Nutrition, Physical Activity, and Metabolism: endorsed by the American College of Cardiology Foundation. Circulation 2007:115:1643-5.

20 American Academy of Family Physicians, American Academy of Pediatrics, American College of Sports Medicine, American Medical Society for Sports Medicine, American Orthopaedic Society for Sports Medicine, Medicine AOAOS. PPE preparticipation physical evaluation 4th edition. 3rd edn. Elk Grove, IL: American Academy of Pediatrics, 2010

21 Van Camp SP, Bloor CM, Mueller FO, et al. Nontraumatic sports death in high school and college athletes. Med Sci Sports Exerc 1995;27:641-7.
22 Corrado D, Basso C, Rizzoli G, et al. Does sports activity enhance the risk of sudden death in adolescents and young adults? J Am Coll Cardiol 2003;42: 1959-63.

23 Steinvil A, Chundadze T, Zeltser D, et al. Mandatory electrocardiographic screening of athletes to reduce their risk for sudden death proven fact or wishful thinking? J Am Coll Cardiol 2011;57:1291-6.

24 Maron BJ, Doerer JJ, Haas TS, et al. Profile and frequency of sudden death in 1463 young competitive athletes: from a 25 year U.S. national registry: 1980-2005. Circulation 2006;114(II, 18):830.

25 Maron BJ. Sudden death in young athletes. N Engl J Med 2003;349:1064-75.

26 Maron BJ, Shirani J, Poliac LC, et al. Sudden death in young competitive athletes. Clinical, demographic, and pathological profiles. JAMA 1996;276:199-204.

27 Corrado D, Basso C, Pavei A, et al. Trends in sudden cardiovascular death in young competitive athletes after implementation of a preparticipation screening program. JAMA 2006;296:1593-601.

28 Maron BJ, Haas TS, Doerer JJ, et al. Comparison of U.S. and Italian experiences with sudden cardiac deaths in young competitive athletes and implications for preparticipation screening strategies. Am J Cardiol 2009;104:276-80.

29 Drezner JA, Rogers KJ, Zimmer RR, et al. Use of automated external defibrillators at NCAA Division I Universities. Med Sci Sports Exerc 2005;37:1487-92.

30 Harmon KG, Drezner JA, Maleszewski JJ, et al. Pathogeneses of sudden cardiac death in national collegiate athletic association athletes. Circ Arrhythm Electrophysiol 2014;7:198-204.

31 Maron BJ, Gohman TE, Aeppli D. Prevalence of sudden cardiac death during competitive sports activities in Minnesota high school athletes. J Am Coll Cardiol 1998;32:1881-4.

32 Maron BJ, Haas TS, Ahluwalia A, et al. Incidence of cardiovascular sudden deaths in Minnesota high school athletes. Heart Rhythm 2013;10:374-7.

33 Winkel BG, Risgaard B, Sadjadieh G, et al. Sudden cardiac death in children (1-18 years): symptoms and causes of death in a nationwide setting. Eur HeartJ 2014;35:868-75

34 Toresdahl BG, Rao AL, Harmon KG, et al. Incidence of sudden cardiac arrest in high school student athletes on school campus. Heart Rhythm 2014. Published Online First. doi: 10.1016/j.hrthm.2014.04.017

35 Harmon KG, Asif IM, Ellenbogen $\mathrm{R}$, et al. The incidence of sudden cardiac arrest in United States high school athletes. Br J Sports Med 2014;48:605.

36 Gunnarsson G. Sudden death in the young: a 30-year nationwide study in Iceland. Eur Soc Cardiol 2006

37 Papadakis M, Sharma S, Cox S, et al. The magnitude of sudden cardiac death in the young: a death certificate-based review in England and Wales. Europace 2009;11:1353-8.

38 Pilmer CM, Kirsh JA, Hildebrandt D, et al. Sudden cardiac death in children and adolescents between 1 and 19 years of age. Heart Rhythm 2014;11:239-45.

39 Margey R, Roy A, Tobin S, et al. Sudden cardiac death in 14- to 35-year olds in Ireland from 2005 to 2007: a retrospective registry. Europace 2011;13: 1411-18.

40 Cooper WO, Habel LA, Sox CM, et al. ADHD drugs and serious cardiovascular events in children and young adults. N Engl J Med 2011;365:1896-904.

41 Atkins DL, Everson-Stewart S, Sears GK, et al. Epidemiology and outcomes from out-of-hospital cardiac arrest in children: the Resuscitation Outcomes Consortium Epistry-Cardiac Arrest. Circulation 2009;119:1484-91.

42 Chugh SS, Reinier K, Balaii S, et al. Population-based analysis of sudden death in children: the Oregon Sudden Unexpected Death Study. Heart Rhythm 2009:6:1618-22.

43 Meyer L, Stubbs B, Fahrenbruch C, et al. Incidence, causes, and survival trends from cardiovascular-related sudden cardiac arrest in children and young adults 0 to 35 years of age: a 30-year review. Circulation 2012;126:1363-72.

44 Eckart RE, Scoville SL, Campbell CL, et al. Sudden death in young adults: a 25-year review of autopsies in military recruits. Ann Intern Med 2004;141:829-34. 